\title{
Mumps prophylaxis in the light of a new test for antibody
}

\author{
P P MORTIMER
}

British Medical fournal, 1978, 2, 1523-1524

\section{Summary and conclusions}

A radial haemolysis test was used to investigate immunity to mumps. Antibody was found in $92(42 \%)$ out of 220 children aged up to 5 years, $124(78 \%)$ out of 159 children aged 6-10 years, $192(86 \%)$ out of 222 children aged 11 years, $138(92 \%)$ out of 150 children aged 15 years, and $280(95 \%)$ out of 296 women attending an antenatal clinic. A group of 307 cadets aged 16-18 years were also tested and interviewed: $133(95 \%)$ out of 140 who said that they had had mumps and $108(87 \%)$ out of 124 who said that they had not had mumps were found to have antibody.

The results suggest that tests for immunity to mumps by radial haemolysis would permit more rational use of mumps-specific immunoglobulin and attenuated mumps vaccine.

\section{Introduction}

Little importance is attached to mumps prophylaxis in the UK, although specific immunoglobulin (MIG, Blood Products Laboratory, Lister Institute, Herts) and attenuated vaccine ${ }^{1}$ (MV, Mumpsvax, Merck Sharp and Dohme) are available. This is partly because prevention is often thought not to be necessary and partly because firm recommendations for the use of MIG and MV have been difficult to formulate. The protective effect of MIG has not been established, as antibody studies have not been carried out on recipients. MV, however, has been shown to be effective ${ }^{2}$ but, in the UK at least, the best means of using it remains to be agreed. Some have argued that to give MV to infants would benefit many people and be costeffective $^{34}$; others have suggested that only susceptible adolescents need to be given vaccine. ${ }^{5}$ But the view that mumps is such a mild illness that immunisation is not justified still prevails.

If mumps prophylaxis were to be offered more widely a good test for antibody would be needed. This would help to decide in individual cases which agent to use and by population studies whether to implement a general immunisation policy. Of the existing tests for mumps antibody, neutralisation is too laborious and haemagglutination inhibition too insensitive and prone to false-positive reactions to be satisfactory. The radial haemolysis (RH) test, ${ }^{6}$ on the other hand, is simple, sensitive, and resistant to non-specific effects. ${ }^{7}$ Its accuracy is comparable to that of the mumps neutralisation test. ${ }^{8}$

In this study $\mathrm{RH}$ was used to determine the extent of immunity to mumps in the UK. Batches of children's and adults' sera were examined, and a group of adolescents from a cadet school were asked to find out whether they had had mumps and were tested for antibody. I present the results and discuss the implications for mumps prophylaxis.

\section{Materials and methods}

The sera were obtained from five sources. Sera from children aged up to 5 years (mostly 4- and 5-year-olds) and 6-10 years had been collected in the London area for diagnostic antistreptolysin $O$ tests. Sera from children aged 11 and 15 were collected in two secondary schools in the home counties. Sera from antenatal patients came from two clinics in north-west London. All sera were collected during 1977-8. A total of 307 cadets at a London training school aged 16-18 years were asked whether they or their families could recall their having mumps. Each gave a sample of venous blood. All sera were stored at $-20^{\circ} \mathrm{C}$ and inactivated at $56^{\circ} \mathrm{C}$ for 30 minutes before $\mathrm{RH}$ tests were carried out.

Mumps virus, Enders strain, was propagated in the allantoic cavity of fertile eggs. The infected allantoic fluids were pooled, divided, and stored in $2 \mathrm{ml}$ volumes at $-70^{\circ} \mathrm{C}$. When thawed and tested in a WHO plastic tray the fluid had a haemagglutinin titre of $1 / 320$ with a $0.5 \%$ suspension of fowl cells. Allantoic fluid from uninfected eggs was similarly treated.

To prepare the RH gels, fowl cells were collected in heparinised saline, washed twice in complement fixation buffer (CFB, Oxoid BR16, with $60 \mathrm{mg}$ benzylpenicillin and $100 \mathrm{mg}$ streptomycin added per litre), and suspended at $10 \% \mathrm{v} / \mathrm{v}$ in the buffer. For each gel $0.2 \mathrm{ml}$ infected fluid was mixed into $2 \mathrm{ml} 10 \%$ cells in a $30 \mathrm{ml}$ screw-capped bottle. After incubation for 10 minutes at room temperature the cells were washed twice and resuspended in $0.5 \mathrm{ml}$ CFB. Undiluted preserved guinea-pig complement $(0.5 \mathrm{ml}$; Wellcome Reagents Ltd) was added to the suspension, which was then placed in a $43^{\circ} \mathrm{C}$ water bath. A $20 \mathrm{ml}$ sample of $1 \%$ agarose (Indubiose, Ind Biol, France, $\mathrm{SA}$ ) in CFB, prepared and maintained at $43^{\circ} \mathrm{C}$ in the water bath, was poured into the suspension. The bottle was rolled between the palms and its contents poured into a $125 \times 85 \mathrm{~mm}$ gel tray (microtitre plate lid, Falcon 3041F, Becton Dickinson Ltd) on a level table. Control gels were prepared in the same way from uninfected allantoic fluid.

After five minutes the gels were transferred to $4^{\circ} \mathrm{C}$ for at least half an hour (they could be stored in this state for up to 24 hours). Wells (diameter $3 \mathrm{~mm}$, capacity $6 \mu \mathrm{l}$ ) were cut in the gels in eight rows of 10 and the specimens added by allowing each serum to be drawn into its well from a microcapillary tube. The gels were then incubated in a humidified box at $37^{\circ} \mathrm{C}$ for 18 hours. The diameters of the zones of haemolysis were measured to the nearest $\mathrm{mm}$ over a light source. Zones of $6 \mathrm{~mm}$ or more were taken to indicate immunity. An aliquot from a pool of human sera was used as a positive control in each batch of tests.

\section{Results}

RH tests on sera from the four younger ag - groups showed that antibody to mumps was usually acquired early in life; it was general in the adults (table I). Ninety-two per cent of the 15-year-olds and $95 \%$ of the pregnant women had antibody.

Tests for antibody in the 307 cadets gave 281 positive, two inconclusive, and 24 negative results (table II). Eighteen of the 213 boys and six of the 94 girls were without antibody. One hundred and forty cadets $(46 \%)$ recalled having mumps, $43(14 \%)$ were uncertain, and $124(40 \%)$ said that they had not had mumps. Of the 140 with

TABLE I-Prevalence of mumps antibody in five age groups

\begin{tabular}{|c|c|c|}
\hline & $\begin{array}{c}\text { No } \\
\text { studied }\end{array}$ & $\begin{array}{c}\text { No }(\%) \\
\text { positive } \\
(\mathrm{RH} \text { zone } \geqslant 6 \mathrm{~mm})\end{array}$ \\
\hline 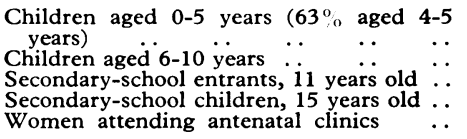 & $\begin{array}{l}220 \\
159 \\
222 \\
150 \\
296\end{array}$ & $\begin{array}{l}92(41 \cdot 8) \\
124(78 \cdot 0) \\
192(86 \cdot 5) \\
138(92 \cdot 0) \\
280(94 \cdot 6)\end{array}$ \\
\hline
\end{tabular}

Virus Reference Laboratory, Central Public Health Laboratory, London NW9 5HT

P P MORTIMER, MD, MRCPATH, consultant microbiologist 
TABLE II-Relation between result of $R H$ test for antibody and history of mumps (307 cadets aged $16-18$ years)

\begin{tabular}{|c|c|c|c|c|c|}
\hline & & \multicolumn{3}{|c|}{ History of mumps } & \multirow{2}{*}{ Total } \\
\hline & & Yes & Don't know & No & \\
\hline $\begin{array}{l}\mathrm{RH} \text { positive }(\geqslant 6 \mathrm{~mm}) \\
\mathrm{RH} \text { negative }(<5 \mathrm{~mm}) \\
\mathrm{RH} \text { inconclusive }(5 \mathrm{~mm})\end{array}$ & $\begin{array}{l}\cdots \\
\cdots \\
\cdots\end{array}$ & $\begin{array}{r}133 \\
5 \\
2\end{array}$ & $\begin{array}{r}40 \\
3\end{array}$ & $\begin{array}{r}108 \\
16\end{array}$ & $\begin{array}{r}281 \\
24 \\
2\end{array}$ \\
\hline \multicolumn{2}{|c|}{ Total } & 140 & 43 & 124 & 307 \\
\hline
\end{tabular}

TABLE III-RH zone diameters in sera from 307 cadets aged $16-18$ years

\begin{tabular}{|c|c|c|c|c|c|c|c|c|c|c|c|c|}
\hline & \multicolumn{11}{|c|}{$\mathrm{RH}$ zone diameter $(\mathrm{mm})$} & \multirow{2}{*}{ Total } \\
\hline & $<5$ & $5^{*}$ & 6 & 7 & 8 & 9 & 10 & $\overline{11}$ & $\overline{12}$ & 13 & 14 & \\
\hline No of specimens & 24 & 2 & 8 & 14 & 24 & 68 & 91 & 49 & 16 & 10 & 1 & 307 \\
\hline
\end{tabular}

infection there has until now been no quick and sensitive test for immunity, and the only course has been to give MIG blindly. Many patients have therefore been treated unnecessarily. A history of mumps may be regarded as evidence of immunity, but $54 \%$ of the cadets in this survey could not recall having mumps, although $89 \%$ of them had antibody. Thus if the RH test were generally available most adult contacts of mumps who lacked a history could be shown to have antibody and reassured. The remainder could be given MIG and followed up to assess the effectiveness of immunoglobulin.

Similarly there cannot at present be a place for the uncontrolled use of MV. My results show that nine out of 10 mumps infections occur in childhood and suggest that half of them are subclinical. As the benefit would prove to be marginal and there are already difficulties in applying the existing schedule of infant vaccination it would be inadvisable to add MV. Nevertheless, MV could be offered to adolescents and adults shown to be susceptible in RH tests. The risk to them of a neurological or

TABLE IV-Age by which mumps had occurred in 73 cadets aged 16-18 years at time of survey, and mean RH zone diameter in each group

\begin{tabular}{|c|c|c|c|c|c|c|c|c|c|c|c|c|c|c|c|c|c|}
\hline Age (years): & 1 & 2 & 3 & 4 & 5 & 6 & 7 & 8 & 9 & 10 & 11 & 12 & 13 & 14 & 15 & 16 & 17 \\
\hline $\begin{array}{l}\text { Cumulative No }\left({ }_{0}^{0}\right) \\
\text { of cases .. } \\
\text { Mean RH zone dia- } \\
\text { meter }(\mathrm{mm})\end{array}$ & $\begin{array}{c}1(1) \\
12\end{array}$ & $4(5)$ & $\begin{array}{c}10(14) \\
10\end{array}$ & $\begin{array}{c}26(36) \\
8^{*}\end{array}$ & $\begin{array}{c}34(47) \\
10\end{array}$ & $\begin{array}{c}46(63) \\
9^{*}\end{array}$ & $\begin{array}{c}56(77) \\
10\end{array}$ & $\begin{array}{c}60(82) \\
9\end{array}$ & $\begin{array}{c}64(88) \\
10\end{array}$ & $\begin{array}{c}66(90) \\
9\end{array}$ & $0(90)$ & $69(95)$ & $\begin{array}{c}71(97) \\
9\end{array}$ & $0(97)$ & $\begin{array}{c}72(99) \\
12\end{array}$ & $0(99)$ & $73(100)$ \\
\hline
\end{tabular}

*Includes a case without antibody ( $\mathrm{RH}$ zone diameter $<5 \mathrm{~mm}$ )

a history of mumps, $133(95 \%)$ definitely and two possibly had antibody (table II). Five cadets with a history of mumps did not have antibody. Two of these knew the year of their illness. Of the 167 without a definite history of mumps, $148(88.6 \%)$ were found to have antibody. Seventy-three cadets could recall when they had had mumps, $66(90 \%)$ of whom said that they had had the illness by the age of 11 .

Zones of lysis in sera from the cadets ranged from less than 5 to $14 \mathrm{~mm}$ diameter (table III), the mean value in positive cases being $10 \mathrm{~mm}$. Table IV gives the results in the cadets with a history of mumps grouped according to the age by which infection was said to have occurred.

\section{Discussion}

With the RH test batches of several hundred sera could be examined by a single worker without difficulty. It was generally found to discriminate clearly between positive and negative sera, and gave indefinite reactions in only $0.7 \%$ of tests (table III). These small-zone reactions-haemolysis $5-6 \mathrm{~mm}$ in diameter-were probably due to low concentrations of antibody, particularly as none of the sera gave reactions in the control plates (false-positive reactions due to anti-fowl-cell activity seemed to arise only when sera were insufficiently heatinactivated). Small-zone reactions were so uncommon, however, that the cost of an error in interpreting them as positive would be higher than that of an error in interpreting them as negative. They were therefore treated as negative.

The high proportion of adults found to have antibody indicates that the test measures a persistent antibody. The evidence from the cadets also suggests that the concentration of antibody does not wane. Whatever the age at which they had been infected the mean RH zone diameter was between 8 and $12 \mathrm{~mm}$ (table IV). The $\mathrm{RH}$ test proved to be sensitive for mumps antibody. Even if the five cadets with a positive history and negative results were assumed to have had mumps, antibody was detected in $95 \%$ of those with a clinically recognisable history; and the high proportion with a negative history and a positive result suggests that the test is equally sensitive to antibody evoked by an atypical or subclinical infection.

When adults without a history of mumps are exposed to gonadal disorder after mumps is considerable, ${ }^{9}$ and either may cause several weeks of disability.

It could be argued that the routine screening of adolescents' sera would be uneconomic, particularly if confined to tests for mumps antibody. But the existence of $\mathrm{RH}$ tests for rubella ${ }^{10}$ and measles, ${ }^{11}$ and the likelihood that similar tests may be developed for poliovirus, ${ }^{12}$ mean that more comprehensive screening may soon be feasible. Trends in the epidemiology of measles $^{13}$ and the failure to immunise all susceptible people against rubella and poliomyelitis suggest that there is a good case for testing and selectively vaccinating this age group against other viruses as well as mumps. In such a programme radial haemolysis would be the method of choice for identifying those to whom vaccines should be offered.

I thank Drs B Musgrave, M S Pereira, J M B Edwards, and E Vandervelde and the cadets and staff of the Metropolitan Police Cadet Training School, whose help and co-operation made this study possible. I began this work during tenure of a travelling fellowship awarded by the Committee on Medical Research of the European Communities.

\section{References}

${ }^{1}$ US Center for Disease Control, Morbidity and Mortality Weekly Report, 1977, 26, 48.

2 Weibel, R E, et al, Pediatrics, 1978, 61, 5.

${ }^{3}$ Bjorvatn, B, and Skoldenberg, B, British Medical fournal, 1978, 1, 788

${ }^{4}$ Harasek, G, Wiener klinische Wochenschrift, 1978, 90, 1.

${ }^{5}$ British Medical fournal, 1977, 2, 1489.

${ }^{6}$ Vaananen, P, et al, Archives of Virology, 1976, 52, 91.

${ }^{7}$ Russell, S M, McCahon, D, and Beare, A S, fournal of General Virology, 1975, 27, 1.

${ }^{8}$ Grillner, L, and Bromberg, J, fournal of Clinical Microbiology, 1976, 4, 11.

${ }^{9}$ Christie, A B, in Infectious Diseases: Epidemiology and Clinical Practice, 2nd edn, p 468. Edinburgh, Churchill Livingstone, 1974.

${ }^{10}$ Shafi, M S, Jordan, J M, and Mortimer, P P, fournal of Medical Microbiology. In press.

11 Weslen, L, Scandinavian fournal of Infectious Diseases, 1978, 10, 15.

${ }^{12}$ Hierholzer, J C, and Tannock, G, fournal of Clinical Microbiology, 1977, $5,613$.

${ }^{13}$ Welliver, R C, Cherry, J D, and Holtzman, A E, Archives of Internal Medicine, 1977, 137, 39.

(Accepted 26 September 1978) 